\title{
First-Episode Psychosis Research in India: A Review
}

\author{
Vijaya Raghavan*, Greeshma Mohan, Seema Jaiswal, Thara Rangaswamy \\ Schizophrenia Research Foudation
}

\begin{abstract}
Background: With the growth of early intervention services for psychosis worldwide, it is imperative to understand the current knowledge on first-episode psychosis (FEP) from Indian context. Hence, the purpose of this review is to comprehensively examine the research studies on FEP from India. This would help to compare and contrast with other countries, develop specialist early intervention services and enlist research priorities pertaining to FEP.
\end{abstract}

Methods: A Boolean search of articles published from January 1990 to March 2018 in electronic database of PubMed and Google Scholar was carried out and original research studies done on first-episode psychosis in India were incorporated in the current review. Case reports and review articles were excluded.

Results: A total of 31 research studies were included for the review and classified into different subheadings of convenience.

Conclusion: Even though the number of studies in Indian context pertaining to FEP is comparatively less than other western literature, the available results indicate certain characteristic similarities and differences in FEP from other parts of the world. We have also discussed on the importance of early intervention in FEP and the necessity for the creation of specialist early intervention services for mental health disorders.

Keywords: First-episode psychosis; Research; India

\section{INTRODUCTION}

First-episode psychosis (FEP) is a major health concern worldwide. ${ }^{1}$ First-episode psychosis is the first presentation of psychotic symptoms and usually occurs in the adolescence or young adulthood. ${ }^{2}$ Individuals with first-episode psychosis present with positive (hallucinations and delusions), negative (apathy and flat affect) and/or cognitive symptoms (attention and memory deficits). ${ }^{3}$ The effect of first-episode psychosis on the individual is immense as it can lead to social disengagement and difficulties in maintaining daily activities. Individuals experiencing first-episode psychosis often present to the Emergency Department of a hospital, with multiple problems, such as aggressive behaviour, suicidal tendencies, and substance misuse, and frequently admitted as involuntary patients. ${ }^{\text {ii } 4}$ Caregivers and other family members could suffer distress often due to aggressive behavior leading to physical and emotional burden of care. As with other psychiatric disorders, stigma and lack of awareness associated with first-episode psychosis is huge and it adversely affects the treatment seeking behavior and early treatment referrals in general population ${ }^{5}$.

Corresponding Author: Dr. Vijayaraghavan

Schizophrenia Research Foundation,

R/7A, North Main Road,

Anna Nagar West Extension,

Chennai, Tamil Nadu, India - 600101 .

email: vijayaraghavan@ scarfindia.org
Over the past two decades, there has been a great upsurge in the interest shown in studies focusing on early intervention for psychosis and this has resulted in many specialised programs worldwide to provide early and timely care for people with psychotic disorders. ${ }^{6}$ Due to this, the duration of untreated psychosis has reduced and has led to better outcomes in individuals with firstepisode psychosis such as decreased hospitalisation/rehospitalizations, early symptom relief and few relapses. ${ }^{7}$ Hence, it is important to educate the health-care professionals and the community on early symptoms of FEP, proper referral and continued support. These interventions could help reduce stigma on mental illness in the community and prevent delays in gaining appropriate early treatment from mental health professionals.

The research on first episode psychosis in India is increasing. It is important to keep abreast of these studies from India as the insights from them will extensively inform the clinicians and other mental health professionals in better management of individuals with first episode psychosis. The objective of this review is to provide an overview of first episode research in India.

\section{MATERIALS AND METHODS Search strategy}

A comprehensive search was carried out using electronic databases of PubMed and Google Scholar for the following combinations: "First episode psychosis" OR 
"First episode schizophrenia" OR "First episode mania" OR "First episode bipolar" AND "India" to identify the research publications from India on FEP. Cross references from the articles and grey literature were also screened.

\section{Study selection}

In this review, we had included peer reviewed studies conducted on individuals with first episode psychosis in India. We had excluded case reports, case series, perspectives and previous review articles on first episode psychosis from this review.

\section{Organisation}

After the search, the identified research articles were screened as per the above-mentioned inclusion and exclusion criteria and organised into various themes such as epidemiology, etiology and pathophysiology, clinical features and comorbidity, management, course and outcome, caregiver burden and interventions.

\section{RESULTS}

Out of 109 research articles screened, 31 were found to be eligible to be included in the current review (Fig 1). All the studies included in this review with their main findings, classified according to different themes, are given in Table 1.

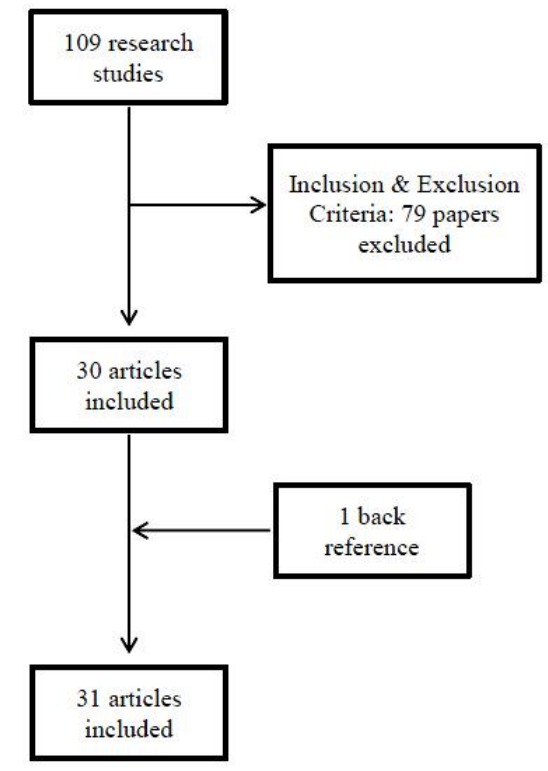

Fig 1. Literature review search flowchart

\section{Epidemiology}

No large-scale community based epidemiological studies have examined the incidence and prevalence of first episode psychosis in India. In a large multi-national, multi-centric collaborative study done in developing and developed countries, nearly $50 \%$ of the individuals with first-episode psychosis were in the age group of 15-24 years. There was a preponderance of males in the younger age group and of females in the older age group. Majority showed no family history with acute onset. $^{8}$

\section{Etiology/ Pathophysiology}

Few studies have examined the pathophysiological basis of first episode psychosis from India. Using fluorine-18 fluorodeoxyglucose (FDG) positron emission tomography (PET), a study examined the correlation between the facial emotional perception task and brain functioning in individuals with first-episode psychosis and found brain regions (bilateral prefrontal cortices and fusiform gyri) implicated in emotion processing showed hypo-metabolism in FEP as compared to controls. ${ }^{9}$ Similarly, drug-naïve first-episode psychosis individuals had smaller global grey matter and increased cerebrospinal fluid (CSF) volumes along with other regional grey matter volume reductions. ${ }^{10}$

While the plasma essential polyunsaturated fatty acids (EPUFAs) levels were found to be comparable between drug-naïve first-episode psychosis and normal controls, docosahexaenoic acid (DHA), which is enriched in the brain, was found to be lower in red blood cells (RBCs) and higher in cerebrospinal fluid (CSF). ${ }^{11}$ Similarly, plasma showed low levels of folate and B12 with increased homocysteine and cortisol levels in individuals with first-episode psychosis. ${ }^{12}$ In a study conducted in individuals with first episode mania, negative correlation and inverse linear relationship were noted between total cholesterol (TC), triglycerides (TG), very low density lipoproteins (VLDL) and body mass index (BMI) with attentional/cognitive impulsivity. ${ }^{13}$

In a qualitative study, the explanatory models of psychosis were explored in individuals with first-episode psychosis. Nearly $70 \%$ had spiritual and mystical factors as the cause of their illness while $22 \%$ held multiple models of illness. Female sex, low education and visits to traditional healers were found to be associated with spiritual and mystic models of illness and likely to be having less insight. ${ }^{14}$

\section{Clinical features and comorbidity}

In a comparative study between India and Canada, Indian subjects showed higher rates of improvement at one year in negative symptoms and functioning than patients receiving similar treatment in Canada but no differences were observed in positive and general psychopathology symptoms. ${ }^{15}$ A study that examined the cognitive deficits in first-episode psyc $\mathrm{c}^{\mathrm{iii}}$ hosis found that nearly $2 / 3^{\text {rd }}$ of the sample had more than $25 \%$ of cognitive deficits and negative symptoms significantly correlated with cognitive functions of motor speed, attention and executive functions. ${ }^{16}$ In a study by Sreedhar et al., no gender differences were observed in the clinical presentation of first episode mania and the 5-year course of bipolar disorder following a first episode mania. ${ }^{17}$ 


\begin{tabular}{|c|c|c|c|c|c|}
\hline S.No. & Author & Type of study & $\begin{array}{l}\text { Subject Character- } \\
\text { istics }\end{array}$ & Methodology & Main findings \\
\hline \multicolumn{6}{|c|}{ Epidemiology } \\
\hline 1. & $\begin{array}{l}\text { Verma } \\
1997 .{ }^{8}\end{array}$ et al., & $\begin{array}{l}\text { Multi-centric } \\
\text { epidemiological } \\
\text { study }\end{array}$ & $\begin{array}{l}\text { Urban and rural } \\
\text { catchment areas with } \\
\text { populations of } \\
348,786 \text { and } \\
103,865 \text {, respectively }\end{array}$ & $\begin{array}{l}\text { Diagnosis and clinical } \\
\text { assessment through } \\
\text { - Structured inter- } \\
\text { views } \\
\text { - Scales }\end{array}$ & $\begin{array}{l}\text { - } 50 \% \text { of the individuals with FEP in the } \\
\text { age group of } 15-24 \\
\text { Male preponderance in younger age } \\
\text { group and of females in the older age } \\
\text { group }\end{array}$ \\
\hline \multicolumn{6}{|c|}{ Etiology/Pathophysiology } \\
\hline 2. & $\begin{array}{l}\text { Choudhary et } \\
\text { al., 2015. }\end{array}$ & $\begin{array}{l}\text { Cross-sectional } \\
\text { study }\end{array}$ & $\mathrm{FEP}=20$ & $\begin{array}{l}\text { - Positron Emission } \\
\text { Topography (PET) } \\
\text { scan }\end{array}$ & $\begin{array}{l}\text { - Hypoactivation of bilateral prefrontal } \\
\text { cortices and fusiform gyrii, with signifi- } \\
\text { cant hyperactivation of bilateral basal } \\
\text { ganglia and left precuneus in FEP } \\
\text { Positive correlation of metabolism in } \\
\text { prefrontal cortex and performance indi- } \\
\text { ces on emotions domain was seen }\end{array}$ \\
\hline 3. & $\begin{array}{l}\text { Jayakumar et al., } \\
2005 .{ }^{10}\end{array}$ & $\begin{array}{l}\text { Cross-sectional } \\
\text { study }\end{array}$ & $\begin{array}{l}\text { First episode schizo- } \\
\text { phrenia }=18 \\
\text { Controls }=18\end{array}$ & $\begin{array}{llr} & \text { Magnetic } & \text { Reso- } \\
\text { nance } & \text { Imaging } \\
(\mathrm{MRI}) \text { scan }\end{array}$ & $\begin{array}{l}\text { - Significantly smaller global grey matter } \\
\text { and greater global cerebrospinal fluid } \\
\text { (CSF) in individuals with schizophrenia }\end{array}$ \\
\hline 4. & $\begin{array}{l}\text { Kale et al., } \\
2008 .{ }^{11}\end{array}$ & $\begin{array}{l}\text { Cross-sectional } \\
\text { study }\end{array}$ & $\begin{array}{l}\mathrm{FEP}=31 \\
\text { Controls }=46\end{array}$ & $\begin{array}{l}\text { Fatty acid analysis } \\
\text { from RBCs, plasma } \\
\text { and CSF }\end{array}$ & $\begin{array}{l}\text { - The plasma Essential Poly Unsaturated } \\
\text { Fatty Acids (EPUFAs) levels were simi- } \\
\text { lar in both groups } \\
\text { Among the EPUFAs enriched in the } \\
\text { brain, predominantly docosahexaenoic } \\
\text { acid (DHA) levels were lower in RBC } \\
\text { whereas higher in CSF in male more } \\
\text { than female patients. }\end{array}$ \\
\hline 5. & $\begin{array}{l}\text { Kale et al., } \\
2010^{12}\end{array}$, & $\begin{array}{l}\text { Cross-sectional } \\
\text { study }\end{array}$ & $\begin{array}{l}\mathrm{FEP}=31 \\
\text { Controls }=48\end{array}$ & $\begin{array}{l}\text { - Fatty acid analysis } \\
\text { Folate, vitamin } \\
\text { B12, homocysteine, } \\
\text { and cortisol deter- } \\
\text { minations }\end{array}$ & $\begin{array}{l}\text { - Significantly lower levels of folate and } \\
\text { vitamin B12 in plasma and folate in red } \\
\text { blood cells were observed in FEP com- } \\
\text { pared to controls with significant in- } \\
\text { crease in plasma homocysteine and cor- } \\
\text { tisol levels } \\
\text { Significantly reduced levels of mem- } \\
\text { brane DHA were also observed in FEP } \\
\text { compared to controls }\end{array}$ \\
\hline 6. & $\begin{array}{l}\text { Saravanan et al., } \\
2007 .{ }^{14}\end{array}$ & $\begin{array}{l}\text { Qualitative } \\
\text { study }\end{array}$ & $\mathrm{FEP}=131$ & - $\quad$ Explanatory models & $\begin{array}{l}\text { - The majority of patients }(70 \%) \text { consid- } \\
\text { ered spiritual and mystical factors as the } \\
\text { cause of their predicament; } 22 \% \text { held } \\
\text { multiple models of illness } \\
\text { Holding of spiritual/mystical models is } \\
\text { associated with female sex, low educa- } \\
\text { tion and visits to traditional healers }\end{array}$ \\
\hline 7. & $\begin{array}{l}\text { Kavoor et al., } \\
\text { 2014. }^{13}\end{array}$, & $\begin{array}{l}\text { Cross-sectional } \\
\text { study }\end{array}$ & $\mathrm{FEP}=60$ & $\begin{array}{l}\text { Barratt impulsive- } \\
\text { ness scale-version } \\
11 \\
\text { - Young Mania Rat- } \\
\text { ing Scale } \\
\text { Lipid profile }\end{array}$ & $\begin{array}{l}\text { - Significant negative correlation and } \\
\text { inverse linear relationship between Total } \\
\text { Cholesterol (TC), Triglycerides (TG), } \\
\text { Very Low Density Lipoproteins } \\
\text { (VLDL) and Body Mass Index (BMI) } \\
\text { with attentional impulsivity. }\end{array}$ \\
\hline \multicolumn{6}{|c|}{ Clinical features and comorbidity } \\
\hline 8. & $\begin{array}{l}\text { Iyer et al., } \\
2010 .\end{array}$ & Follow-up study & $\begin{array}{l}\mathrm{FEP}=149(\text { India }= \\
61 ; \text { Canada }=88)\end{array}$ & $\begin{array}{ll}\text { - } & \text { Psychopathology } \\
\text { - } & \text { Functional out- } \\
\text { comes }\end{array}$ & $\begin{array}{l}\text { - First-episode patients in the Indian } \\
\text { program demonstrated higher rates of } \\
\text { improvement at one year in negative } \\
\text { symptoms and functioning than patients } \\
\text { receiving similar treatment in Canada. } \\
\text { There was no difference in improvement } \\
\text { between the sites on positive symptoms } \\
\text { and general psychopathology. }\end{array}$ \\
\hline 9. & $\begin{array}{l}\text { Hegde } \\
\text { 2013. }^{16}\end{array}$ et al. & $\begin{array}{l}\text { Cross-sectional } \\
\text { study }\end{array}$ & $\mathrm{FEP}=49$ & $\begin{array}{ll}- & \text { Psychopathology } \\
\text { - Neuropsychological } \\
\text { functioning } \\
\text { - WHO Disability } \\
\text { assessment sched- } \\
\text { ule }\end{array}$ & $\begin{array}{l}\text { - Cognitive deficits in multiple domains } \\
\text { were observed. } \\
\text { Attention and executive functions pre- } \\
\text { dicted global functioning. }\end{array}$ \\
\hline 10. & $\begin{array}{l}\text { Gunasekaran et } \\
\text { al., 2016. }\end{array}$ & $\begin{array}{l}\text { Cross-sectional } \\
\text { study }\end{array}$ & $\mathrm{FEP}=30$ & $\begin{array}{l}\text { Cambridge Neuro- } \\
\text { logical Inventory }\end{array}$ & $\begin{array}{l}\text { - } 93.3 \% \text { of patients with FEP had at least } \\
\text { one soft neurological sign compared to } \\
16.6 \% \text { of controls. }\end{array}$ \\
\hline
\end{tabular}

(C) Indian Journal of Metal Health and Neurosciences 


\begin{tabular}{|c|c|c|c|c|c|}
\hline 11. & $\begin{array}{l}\text { Chand } \\
2014 .{ }^{19}\end{array}$ et al., & $\begin{array}{l}\text { Cross-sectional } \\
\text { study }\end{array}$ & $\mathrm{FEP}=139$ & $\begin{array}{llr}- & \text { Urine } & \text { toxicology } \\
\text { screen } & \\
\text { - } & \text { Breath alcohol } \\
& \text { analysis }\end{array}$ & $\begin{array}{l}\text { - } 20 \% \text { of the population reported current } \\
\text { substance use disorder (excluding nico- } \\
\text { tine). } \\
\text { Current alcohol dependence was diag- } \\
\text { nosed among } 17.3 \% \text {, whereas cannabis } \\
\text { dependence in } 3.6 \% \text {. } \\
\text { Life time as well as current use of can- } \\
\text { nabis was less than } 6 \% \text {. }\end{array}$ \\
\hline 12. & $\begin{array}{l}\text { Saddichha et al., } \\
2008 .^{20}\end{array}$ & $\begin{array}{l}\text { Randomized } \\
\text { controlled trial }\end{array}$ & $\mathrm{FEP}=99$ & $\begin{array}{l}\text { Fasting and } 2 \mathrm{~h} \\
\text { post-prandial plas- } \\
\text { ma glucose meas- } \\
\text { urements }\end{array}$ & $\begin{array}{l}\text { - Male patients with schizophrenia are } \\
\text { liable to develop diabetes Mellitus } \\
\text { (DM). } \\
\text { Antipsychotic treatment leads to the } \\
\text { development of DM in a significant } \\
10.1 \% \text { within } 6 \text { weeks. }\end{array}$ \\
\hline 13. & $\begin{array}{l}\text { Saddichha et al., } \\
2007 .{ }^{22}\end{array}$ & Follow-up study & $\begin{array}{l}\text { FEP }=30 \quad \text { all fe- } \\
\text { males) }\end{array}$ & $\begin{array}{l}\text { - } \quad \text { Lipid/glucose pro- } \\
\text { file } \\
\text { Blood pressure and } \\
\text { waist circumfer- } \\
\text { ence measurement }\end{array}$ & $\begin{array}{l}\text { Even the six-week therapy with antipsy- } \\
\text { chotics can cause significant changes in } \\
\text { lipid as well as anthropometric measures }\end{array}$ \\
\hline 14. & $\begin{array}{l}\text { Saddichha et al., } \\
2007 .{ }^{21}\end{array}$ & $\begin{array}{l}\text { Randomized } \\
\text { controlled trial }\end{array}$ & $\mathrm{FEP}=66$ & $\begin{array}{ll} & \text { Anthropometric } \\
\text { measurements }\end{array}$ & $\begin{array}{l}\text { - Prevalence of overweight (WHO crite- } \\
\text { ria) was } 22.7 \% \text { and obesity was } 31.8 \% \\
\text { (IDF criteria) } \\
\text { - Subjects in the olanzapine group had the } \\
\text { greatest weight gain at } 5.1 \mathrm{~kg} \text {, followed } \\
\text { by risperidone at } 4.1 \mathrm{~kg} \text { and haloperidol } \\
\text { at } 2.8 \mathrm{~kg} \text {. }\end{array}$ \\
\hline 15. & $\begin{array}{l}\text { Saddichha et al., } \\
2008 .^{23}\end{array}$ & $\begin{array}{l}\text { Randomized } \\
\text { controlled trial }\end{array}$ & $\mathrm{FEP}=99$ & $\begin{array}{ll}\text { - } & \text { Anthropometric } \\
\text { measurements }\end{array}$ & $\begin{array}{l}\text { - Waist circumference and weight at } \\
\text { baseline in addition to the disease pro- } \\
\text { cess as well as antipsychotic use were } \\
\text { associated with greater increases in } \\
\text { weight and BMI. }\end{array}$ \\
\hline 16. & $\begin{array}{l}\text { Sreedhar et al., } \\
\text { 2017. }^{18}\end{array}$ & $\begin{array}{l}\text { Retrospective } \\
\text { study }\end{array}$ & $\mathrm{FEP}=108$ & - $\quad$ Clinical variables & $\begin{array}{l}\text { - No gender difference in the 5-year } \\
\text { course of Bipolar Disorder (BD), fol- } \\
\text { lowing a first manic episode was ob- } \\
\text { served in the clinical variables }\end{array}$ \\
\hline \multicolumn{6}{|c|}{ Course and outcome } \\
\hline 17. & 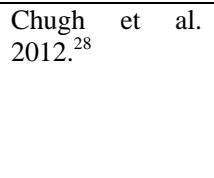 & $\begin{array}{l}\text { Cross-sectional } \\
\text { study }\end{array}$ & $\mathrm{FEP}=55$ & $\begin{array}{ll}- & \text { WHOQOL-Bref } \\
& \text { PANSS }\end{array}$ & $\begin{array}{l}\text { Physical well-being as assessed with } \\
\text { WHOQOL-Bref is significantly impact- } \\
\text { ed by the positive, negative and general } \\
\text { psychopathology symptoms of the dis- } \\
\text { ease. }\end{array}$ \\
\hline 18. & $\begin{array}{l}\text { Johnson } \\
2013{ }^{29}\end{array}$ et al. & Follow-up study & $\mathrm{FEP}=95$ & $\begin{array}{ll} & \text { Psychopathology } \\
\text { - } & \text { Functioning } \\
\text { - } & \text { Insight } \\
\text { - } & \text { Disability }\end{array}$ & $\begin{array}{l}\text { Disability at } 5 \text { years was associated with } \\
\text { illness variables - episodic nature of ill- } \\
\text { ness at baseline, psychopathology and } \\
\text { functioning, duration in psychotic epi- } \\
\text { sode and return to pre-morbid function. }\end{array}$ \\
\hline 19. & $\begin{array}{l}\text { Johnson } \\
2014 .^{30}\end{array}$ et al. & Follow-up study & $\mathrm{FEP}=95$ & $\begin{array}{ll} & \text { Psychopathology } \\
- & \text { Functioning } \\
- & \text { Insight }\end{array}$ & $\begin{array}{l}\text { A relationship was found between in- } \\
\text { sight, psychosis rating and explanatory } \\
\text { models of illness with good insight and } \\
\text { medical models associated with good } \\
\text { outcome. }\end{array}$ \\
\hline 20. & $\begin{array}{l}\text { Shrivastava } \\
\text { al., 2010. }{ }^{26}\end{array}$ & Follow-up study & $\mathrm{FEP}=101$ & $\begin{array}{ll}- & \text { Duration of un- } \\
\text { treated psychosis } \\
-\quad & \text { Psychopathology } \\
- & \text { Functioning }\end{array}$ & $\begin{array}{l}\text { Duration of Untreated Psychosis (DUP) } \\
\text { was not found to be significantly associ- } \\
\text { ated with any of the end point parame- } \\
\text { ters of good clinical or social outcome. }\end{array}$ \\
\hline 21. & $\begin{array}{l}\text { Rangaswamy et } \\
\text { al., 2012. }{ }^{32}\end{array}$ & Follow-up study & $\mathrm{FEP}=47$ & $\begin{array}{ll} & \text { Psychopathology } \\
\text { - } & \text { Functioning }\end{array}$ & $\begin{array}{l}\text { Significant improvement from baseline } \\
\text { to } 1 \text { st year with maximal improvement } \\
\text { seen at } 3 \text { months after intake } \\
\text { More women relapsed and more men } \\
\text { dropped out. } \\
\text { - } \\
\text { PANSS scores and GAF at baseline are } \\
\text { not predictive of later outcomes. }\end{array}$ \\
\hline 22. & $\begin{array}{l}\text { Iyer et al., } \\
20111^{33}\end{array}$ & $\begin{array}{l}\text { Qualitative } \\
\text { study }\end{array}$ & $\mathrm{FEP}=68$ & $\begin{array}{lll}- & \text { Goal Attainment } \\
\text { section of the Wis- } \\
\text { consin Quality of }\end{array}$ & $\begin{array}{l}\text { The primary goals identified pertained } \\
\text { to work, family/interpersonal relation- } \\
\text { ships, education, symptom relief and }\end{array}$ \\
\hline
\end{tabular}

(C) Indian Journal of Metal Health and Neurosciences 


\begin{tabular}{|c|c|c|c|c|c|}
\hline & & & & $\begin{array}{l}\text { Life-Client Ques- } \\
\text { tionnaire }\end{array}$ & $\begin{array}{l}\text { psychological recovery, living condi- } \\
\text { tion, religion, finances, and household } \\
\text { responsibilities. }\end{array}$ \\
\hline 23. & $\begin{array}{l}\text { Shrivastava } \\
\text { al., 2011. }\end{array}$ & Follow-up study & $\mathrm{FEP}=61$ & $\begin{array}{ll}\text { - } & \text { Psychopathology } \\
\text { - } & \text { Functioning }\end{array}$ & $\begin{array}{l}\text { - Not all patients who show clinical re- } \\
\text { covery have also improved in social } \\
\text { functions on socially relevant parame- } \\
\text { ters. } \\
\text { - Half of the patients continued to have } \\
\text { limitations in the areas of social function }\end{array}$ \\
\hline 24. & $\begin{array}{l}\text { Raghavan et al., } \\
2017 .^{31}\end{array}$ & Follow-up study & $\mathrm{FEP}=51$ & $\begin{array}{ll}\text { - } & \text { Life skills Profile } \\
\text { scale } & \\
\text { - } & \text { Functioning }\end{array}$ & $\begin{array}{l}\text { - Significant improvement was seen in } \\
\text { certain domains of social functioning } \\
\text { such as communication and non- } \\
\text { turbulence while no significant changes } \\
\text { were observed in self-care and social } \\
\text { contact. }\end{array}$ \\
\hline \multicolumn{6}{|c|}{ Caregiver burden } \\
\hline 25. & $\begin{array}{l}\text { Tharoor et al., } \\
2015 .^{34}\end{array}$ & $\begin{array}{l}\text { Cross-sectional } \\
\text { study }\end{array}$ & $\begin{array}{l}\text { Caregivers of FEP }= \\
40\end{array}$ & $\begin{array}{l}\text { - Semi-structured } \\
\text { questionnaire to } \\
\text { identify the various } \\
\text { symptoms cluster } \\
\text { recognized by care- } \\
\text { givers at illness on- } \\
\text { set in first episode } \\
\text { schizophrenia }\end{array}$ & $\begin{array}{l}\text { - Depressive, anxious, irritable, and vege- } \\
\text { tative factor were the early symptom } \\
\text { clusters identified by caregivers at ill- } \\
\text { ness onset in first episode schizophrenia }\end{array}$ \\
\hline 26. & $\begin{array}{l}\text { Sadath et al., } \\
\text { 2017.35 }\end{array}$ & $\begin{array}{l}\text { Cross-sectional } \\
\text { study }\end{array}$ & $\begin{array}{l}\text { Caregivers of FEP }= \\
71\end{array}$ & 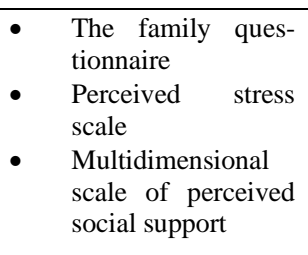 & $\begin{array}{l}\text { - Caregivers experienced high level of } \\
\text { perceived stress, Expressed Emotion } \\
\text { (EE) and poor social support. } \\
\text { Perceived stress significantly increased } \\
\text { EE and social support did not signifi- } \\
\text { cantly influence EE. }\end{array}$ \\
\hline \multicolumn{6}{|c|}{ Management } \\
\hline 27. & $\begin{array}{l}\text { Shrivastava } \\
\text { al., 2012. }\end{array}$ & Follow-up study & $\begin{array}{l}\text { FEP }=60(\mathrm{M}=30 ; \mathrm{F} \\
=30) \\
\text { Controls }=31\end{array}$ & $\begin{array}{lll}- & \text { Serum prolactin } \\
& \text { levels } & \\
\text { - } & \text { BPRS } & \\
\text { - } & \text { GAF } & \end{array}$ & 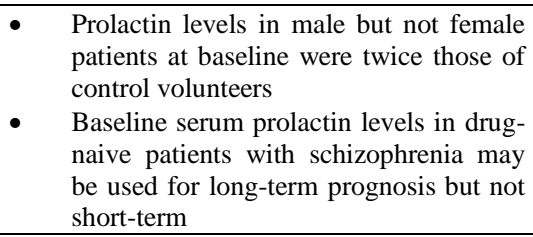 \\
\hline 28. & $\begin{array}{l}\text { Sahni et al., } \\
2016 .^{37}\end{array}$ & $\begin{array}{l}\text { Randomized } \\
\text { controlled trial }\end{array}$ & $\mathrm{FEP}=63$ & $\begin{array}{ll}- & \text { PANSS } \\
\text { - } & \text { Glasgow Antipsy- } \\
\text { chotic Side-effect } \\
\text { Scale }\end{array}$ & $\begin{array}{l}\text { Clozapine as a better choice than risper- } \\
\text { idone in terms of efficacy, tolerability } \\
\text { and better quality of life in treatment- } \\
\text { naive, first-episode schizophrenia }\end{array}$ \\
\hline 29. & $\begin{array}{l}\text { Hedge et al., } \\
2012 .{ }^{38}\end{array}$ & $\begin{array}{l}\text { Randomized } \\
\text { controlled trial }\end{array}$ & $\mathrm{FEP}=45$ & $\begin{array}{ll}\text { - } & \text { Psychopathology } \\
\text { - } & \text { Neuropsychological } \\
& \text { functions } \\
\text { - } & \text { Global functioning }\end{array}$ & $\begin{array}{l}\text { - Addition of home-based cognitive re- } \\
\text { training along with Treatment as Usual } \\
\text { (TAU) led to significant improvement in } \\
\text { neuropsychological functions of divided } \\
\text { attention, concept formation and set- } \\
\text { shifting ability, and planning. }\end{array}$ \\
\hline 30. & $\begin{array}{ll}\text { Shrivastava } & \text { et } \\
\text { al., 2012. } & \end{array}$ & $\begin{array}{l}\text { Cross-sectional } \\
\text { study }\end{array}$ & $\mathrm{FEP}=116$ & $\begin{array}{l}\text { Assessment of } \\
\text { medication adher- } \\
\text { ence by predeter- } \\
\text { mined cut-off value }\end{array}$ & $\begin{array}{l}\text { - In long term, FEP use prescribed atypi- } \\
\text { cal antipsychotics within the recom- } \\
\text { mended limits. } \\
\text { Chlorpromazine equivalence dosages do } \\
\text { not differ across antipsychotic medica- } \\
\text { tions }\end{array}$ \\
\hline 31. & $\begin{array}{l}\text { Morgan } \\
2015.4\end{array}$ et al., & $\begin{array}{l}\text { Mixed methods } \\
\text { study }\end{array}$ & & $\begin{array}{l}\text { - Structure of mental } \\
\text { health systems in } \\
\text { three catchments } \\
\text { areas, namely } \\
\text { Chengalpet, Ibadan } \\
\text { and Trinidad. }\end{array}$ & $\begin{array}{l}\text { - Marked differences in mental health } \\
\text { systems in each catchment areas } \\
\text { Highlights the necessity of developing } \\
\text { tailored systems for the detection of rep- } \\
\text { resentative samples of cases with un- } \\
\text { treated and first-episode psychosis as a } \\
\text { basis for robust, comparative epidemio- } \\
\text { logical studies. }\end{array}$ \\
\hline
\end{tabular}


There is a significantly higher incidence of soft neurological signs in patients with first-episode psychosis $(93.3 \%)$ when compared with normal controls (16.6\%). Also, the presence of soft signs correlated with the severity of psychosis. ${ }^{18}$

In a study from Bangalore, the prevalence of substance use in individuals with first-episode psychosis was examined by self-report questionnaire, urine toxicity screen and alcohol breath analysis. Here, current alcohol dependence was found to be $17.3 \%$ while cannabis dependence was $3.6 \%{ }^{19}$ When compared with western countries such as UK, Canada and USA, the prevalence of substance use in Indian urban setting is substantially less among individuals with first-episode psychosis.

Individuals with drug-naïve first-episode psychosis were found to have significantly higher $2 \mathrm{~h}$ postprandial blood sugar (PPBS) levels when compared with normal controls indicating they are inherently susceptible to develop diabetes mellitus. ${ }^{20}$ In a similar study, women with first-episode psychosis were serially followed-up for six weeks and found to have significant abnormalities in lipid profile and anthropometric measures. $^{21}$

There is high prevalence of overweight at $22.7 \%$ and obesity at $31.8 \%$ in individuals with first-episode psychosis treated with atypical antipsychotic drugs with highest risk for individuals treated with olanzapine. ${ }^{22}$ Similarly, prevalence of metabolic syndrome (MetS) was $10.1 \%$ which is five times higher than the normal control group. Moreover, Olanzapine had maximum prevalence of MetS at 20-25\% followed by risperidone at $9-24 \%$ and haloperidol at $0-3 \% .^{23}$ Predictors of antipsychotic-induced weight gain were waist circumference and weight at baseline, disease process and antipsychotic use especially olanzapine $(77 \%){ }^{24}$

\section{Course and outcome}

Serum prolactin levels at baseline were found to predict long-term (5 years) outcome in individuals with first-episode psychosis. ${ }^{25}$ In this longitudinal naturalistic follow-up study, individuals with FEP who were hospitalised were selected and followed up for 10 years. The results showed that the DUP was not significantly associated with any of the end-point variables indicative of good clinical and social outcomes. This study hinted that DUP alone does not determine the outcome in FEP with multiple other factors playing important roles. ${ }^{26}$ Also, individuals with good clinical outcome were assessed for social recovery. 52.5\% of patients showed good social recovery while the others showed variable social recovery highlighting the discordance between the clinical and social outcomes in first-episode psychosis. ${ }^{27}$

In a follow-up study of 6 months, the different facets of quality of life (QOL) was strongly associated with the general psychopathology symptoms measured in Positive and Negative Symptoms Scale (PANSS) and nega- tive symptoms have a greater influence on the subjective QOL than the positive symptoms. ${ }^{28}$

In a study by Johnson et al., at the end of 5-years, disability in first-episode psychosis was found to be associated with episodic nature of illness at baseline, psychopathology and functioning, duration in psychotic episode and return to pre-morbid functioning. ${ }^{29}$ Similarly, the same author had examined the predictors of insight in first-episode psychosis. In this 5-year follow-up, $\mathrm{re}^{\mathrm{iv}}$ sults suggested a relationship between the insight, psychosis ratings and explanatory models of illness indicating that the insight and explanatory models of illness are secondary to psychopathology, course and outcome. Moreover, early improvement in insight was found to be a useful clinical guide to predict future outcomes in first-episode psychosis. ${ }^{30}$

Individuals with first-episode psychosis were found to have only partial improvement in social functioning at the end of one year treatment with better improvements in communication and non-turbulence while no significant changes observed in self-care and social contact. ${ }^{31}$ In individuals with first-episode psychosis who had attained remission, 50\% attained maximum improvement within the first three months of treatment while $30 \%$ at 1 year, and the remaining $20 \%$ at 2 years. Moreover, 25 out of 28 individuals with shorter duration of untreated psychosis ( $<2$ years) were found to be in remission at the end of 2-year follow-up while only 3 out of 10 individuals were in remission when their duration of untreated psychosis was more than two years. ${ }^{32}$

Interestingly, when patient identified goals of treatment were explored in FEP, the following were the primary goals: work, family/interpersonal relationships, education, symptom relief and psychological recovery, living condition, religion, finances, and household responsibilities. $^{33}$

\section{Caregiver burden}

Few studies have examined the first episode psychosis from the caregivers' perspective. In one study by Tharoor and colleagues, the various symptom clusters recognised by the caregivers at the illness onset of FEP were examined. Using Principal Component (PCP) analysis, it was identified that four factors were easily recognised by the caregivers namely, depressive, anxious, irritable, and vegetative factor. ${ }^{34}$ Another study examined the expressed emotion in caregivers of individuals with first-episode psychosis shaped by stress and social support to them. The results indicated that caregivers experienced high level of perceived stress, expressed emotion and poor social support. ${ }^{35}$

\section{Management}

Many individuals with first-episode psychosis showed high compliance with medications and nearly $77 \%$ of them were prescribed atypical antipsychotics. The clin- 
ical and functional outcomes in different atypical antipsychotic groups were also comparable. ${ }^{36}$

In comparative, open-label, six-months prospective study of drug-naïve first-episode psychosis, clozapine was found to be a better in terms of efficacy, tolerability and better quality of life when compared with risperidone. $^{37}$

In an intervention study, 2-month-long home-based cognitive retraining program together with treatment as usual (TAU; psychoeducation and drug therapy) was found leading towards a significant improvement in neuropsychological functioning when compared with controls (TAU). ${ }^{38}$

Introduction of a round-the-clock crisis helpline for suicide prevention had been effective in the identification of individuals with first-episode psychosis. These individuals were found to have a shorter duration of untreated psychosis (DUP) and fewer suicide attempts. $^{39}$

Marked differences in the mental health system in the western countries when compared with developing countries like India had made it difficult to translate the findings for practical applications. This had illustrated the need for the development of tailored mental health system applicable to the Indian context for the early detection and management of first-episode psychosis. ${ }^{40}$

\section{DISCUSSION}

The aim of the current study was to comprehensively summarise the scientific literature available on firstepisode psychosis from the Indian subcontinent. These studies from India have explored the varied dimensions of FEP from neurobiological underpinnings of the disorder to social and cultural factors playing a role in the treatment outcomes. Even though the research output on FEP is less when compared with the western world, the results from these studies have given significant insights applicable specifically for our population. For example, a comparative study by SCARF among individuals with FEP from India and Canada has shown certain similarities and significant differences existing between the study population and various social and cultural factors have been found to play an interactive role in this respect.

Previous research has shown that there is a significant delay between the onset of psychotic symptoms and the commencement of treatment. It may take up to 2 years for individuals to begin to receive the interventions needed to alleviate psychotic symptoms. ${ }^{41}$ Similar results are also found in studies from India ${ }^{15,31}$. This delay could be twofold in nature, with delays occurring due to individuals not seeking help, and scarcity of mental health professionals in India.

Individuals often do not seek treatment as they do not understand the nature of their psychotic symptoms, especially in the prodromal phase. ${ }^{42}$ Delays in seeking assistance can also be due to fear of stigmatisation, psychological factors such as denial, and lack of support or motivation. ${ }^{43,44}$ Moreover, in India, the common prevalence of religious explanatory models for the causation of psychosis in the general population against biomedical models play a significant role for this delay. This has led to the process of people with FEP accessing the care from the magico-religious centers first and then seeking help from the mental health professionals. ${ }^{14}$ This causes a significant delay in the initiation of proper treatment. Lack of access to relevant services may also impair an individual's ability to access treatment. Individuals in rural areas face greater barriers to treatment, with less psychiatry services available, poorer socioeconomic status, and generally a lack of critical mass of patients in these areas.

Most of the longitudinal follow-up studies from this review have highlighted the importance of early interventions in FEP as it leads to better treatment outcomes and functioning in the long term. There is considerable debate in the literature as to whether early intervention leads to better clinical outcomes in individuals with FEP. Some studies show no difference in outcomes for patients with longer or shorter duration of untreated psychosis (DUP). ${ }^{45}$ Similar finding was also found in a study from India which has shown that there is no relationship between DUP and functional outcome in individuals with $\mathrm{FEP}^{26}$ Others, however, show a longer course of illness $\mathrm{w}^{\mathrm{v}}$ ith more severe symptoms in those individuals with longer DUP. Shiers et al., ${ }^{41}$ argue that the early stage of psychotic illness is a crucial time for intervention, with outcomes at 2 years after symptom onset predictive of illness severity 15 years later. Even though no such long-term follow-up studies are there from India, the trends from the existing literature points towards this direction. Moreover, Berger et al., ${ }^{46}$ state that early intervention is imperative, as functional and structural brain changes seen in schizophrenia may actually occur at the onset of psychotic symptoms. Research suggests that deterioration is most rapid in the 2-3 years after onset of psychotic illness, so early intervention may halt this decline. ${ }^{3}$

Even though the debate remains, early intervention is essential when we look at the psychological impact on both patient and their family as discussed earlier. ${ }^{43}$ Delays in treatment prolong anxiety and distress for patients and their families, and can lead to an increased risk of relapse. ${ }^{47}$ Importantly, it is vital to alleviate psychotic symptoms as it is known that they increase the risk of suicide and suicidal behavior. ${ }^{48}$

In order to facilitate early intervention, education related to early detection needs to be given to both healthcare professionals and the community. ${ }^{7}$ GPs, nurses, and other health-care workers need to be educated as to the early identification of psychotic symptoms and their assessment, and then be encouraged to either begin treatment or refer patients to appropriate specialist services. $^{46}$ 
Second, community stakeholders and carers of young people also need to be aware of early symptoms. Teachers, counsellors, the police, and others who may have ongoing contact with youth in the community need to be taught about the symptoms of psychosis, be encouraged to seek help for young people of whom they are concerned, and be shown where that help may be found. ${ }^{44,49}$ Individuals themselves also need to be supported to change their help-seeking behaviour, with information and access to services being readily available. $^{43}$

In order to combat the barriers to early treatment, a number of early intervention services have emerged. ${ }^{50}$ In Victoria, Australia, for example, the Early Psychosis Prevention and Intervention Centre (EPPIC) has a mobile assessment team which takes referrals from GPs, the police, and concerned relatives and friends to respond in a timely manner when individuals display potentially psychotic symptoms. ${ }^{51}$ The EPPIC is part of Orygen Youth Health which targets youth aged 13-25 years, attempting to bridge the gap between child and adult mental health services. ${ }^{52}$

\section{CONCLUSION}

This review analyzed the research conducted on first episode psychosis in India. When compared other parts of the world, the research output from India in firstepisode psychosis is less but steadily on the rise in the recent times. Given the importance of first episode psychosis and its early identification and treatment for better outcomes, the need of the hour is the dedicated research focus on first episode psychosis to understand the disorder in the Indian context and to develop strategies to manage within the framewor ${ }^{\mathrm{vi}} \mathrm{k}$ of available facilities in India.

\section{ACKNOWLEDGEMENTS}

Post-Doctoral support is by the Fogarty International Training Program in Chronic Non-Communicable Diseases and Disorders at the University of Florida, Grant \# 1D43TW009120 (L. Cottler, PI) (VR).

\section{REFERENCES}

1. Baldwin P, Browne D, Scully PJ, Quinn JF, Morgan MG, Kinsella A, et al. Epidemiology of first-episode psychosis: illustrating the challenges across diagnostic boundaries through the CavanMonaghan study at 8 years. Schizophr Bull 2005; 31(3):624-638.

2. Harris A, Brennan J, Anderson J, Taylor A, Sanbrook M, Fitzgerald D, et al. Clinical profiles, scope and general findings of the Western Sydney First Episode Psychosis Project. Aust N Z J Psychiatry. 2005;39(1-2):36-43.

3. Payne J, Malla A, Norman R, Windell D, Brown N. Status of firstepisode psychosis patients presenting for routine care in a defined catchment area. Can J Psychiatry. 2006;51(1):42-47.

4. Malla AK, Norman RM, Joober R. First-episode psychosis, early intervention, and outcome: what have we learned? Can J Psychiatry. 2005;50(14):881-891.
5. Franz L, Carter T, Leiner AS, Bergner E, Thompson NJ, Compton MT. Stigma and treatment delay in first-episode psychosis: a grounded theory study. Early Interv Psychiatry. 2010;4(1):47-56.

6. McGorry PD. Early intervention in psychosis: obvious, effective, overdue. J Nerv Ment Dis. 2015;203(5):310.

7. McGorry PD, Killackey E, Yung A. Early intervention in psychosis: concepts, evidence and future directions. World Psychiatry. 2008;7(3):148-156.

8. Varma VK, Wig NN, Phookun HR, Misra AK, Khare CB, Tripathi $\mathrm{BM}$, et al. First-onset schizophrenia in the community: relationship of urbanization with onset, early manifestations and typology. Acta Psychiatr Scand. 1997 Dec;96(6):431-8.

9. Choudhary M, Kumar A, Tripathi M, Bhatia T, Shivakumar V, Beniwal RP, et al. F-18 fluorodeoxyglucose positron emission tomography study of impaired emotion processing in first episode schizophrenia. Schizophr Res. 2015 Mar;162(1-3):103-7.

10. Jayakumar PN, Venkatasubramanian G, Gangadhar BN, Janakiramaiah N, Keshavan MS. Optimized voxel-based morphometry of gray matter volume in first-episode, antipsychotic-naive schizophrenia. Prog Neuropsychopharmacol Biol Psychiatry. 2005 May;29(4):587-91.

11. Kale A, Joshi S, Naphade N, Sapkale S, Raju MSVK, Pillai A, et al. Opposite changes in predominantly docosahexaenoic acid (DHA) in cerebrospinal fluid and red blood cells from never-medicated firstepisode psychotic patients. Schizophr Res. 2008 Jan;98(1-3):295301.

12. Kale A, Naphade N, Sapkale S, Kamaraju M, Pillai A, Joshi S, et al. Reduced folic acid, vitamin B12 and docosahexaenoic acid and increased homocysteine and cortisol in never-medicated schizophrenia patients: implications for altered one-carbon metabolism. Psychiatry Res. 2010 Jan 30;175(1-2):47-53.

13. Kavoor AR, Ram D, Mitra S. Lipid correlates of attentional impulsivity in first episode mania: results from an Indian population. Indian J Psychol Med. 2014;36(4):378.

14. Saravanan B, Jacob KS, Johnson S, Prince M, Bhugra D, David AS. Belief models in first episode schizophrenia in South India. Soc Psychiatry Psychiatr Epidemiol. 2007 Jun;42(6):446-51.

15. Iyer SN, Mangala R, Thara R, Malla AK. Preliminary findings from a study of first-episode psychosis in Montreal, Canada and Chennai, India: comparison of outcomes. Schizophr Res [Internet]. 2010 [cited 2016 Jun 26];121(1):227-233. Available from: http://www.sciencedirect.com/science/article/pii/S092099641001353 8

16. Hegde S, Thirthalli J, Rao SL, Raguram A, Philip M, Gangadhar BN. Cognitive deficits and its relation with psychopathology and global functioning in first episode schizophrenia. Asian J Psychiatry. 2013 Dec;6(6):537-43.

17. Sreedhar D, Kulkarni KR, Purty A, Muralidharan K, Reddy YJ, Jain S. Gender differences in the 5 years course of bipolar disorder after a first manic episode: A retrospective review. Indian J Psychol Med. 2017;39(5):712.

18. Gunasekaran V, Venkatesh VMK, Asokan TV. A Study of Soft Neurological Signs and Its Correlates in Drug-Naive Patients with First Episode Psychosis. Indian J Psychol Med. 2016 Oct;38(5):40813.

19. Chand P, Thirthalli J, Murthy P. Substance use disorders among treatment naïve first-episode psychosis patients. Compr Psychiatry. 2014 Jan;55(1):165-9. 
20. Saddichha S, Manjunatha N, Ameen S, Akhtar S. Diabetes and schizophrenia - effect of disease or drug? Results from a randomized, double-blind, controlled prospective study in first-episode schizophrenia. Acta Psychiatr Scand. 2008 May;117(5):342-7.

21. Saddichha S, Ameen S, Akhtar S. Incidence of new onset metabolic syndrome with atypical antipsychotics in first episode schizophrenia: a six-week prospective study in Indian female patients. Schizophr Res. 2007 Sep;95(1-3):247.

22. Saddichha S, Manjunatha N, Ameen S, Akhtar S. Effect of olanzapine, risperidone, and haloperidol treatment on weight and body mass index in first-episode schizophrenia patients in India: a randomized, double-blind, controlled, prospective study. J Clin Psychiatry. 2007 Nov;68(11):1793-8.

23. Saddichha S, Manjunatha N, Ameen S, Akhtar S. Metabolic syndrome in first episode schizophrenia - a randomized double-blind controlled, short-term prospective study. Schizophr Res. 2008 Apr;101(1-3):266-72.

24. Saddichha S, Ameen S, Akhtar S. Predictors of antipsychoticinduced weight gain in first-episode psychosis: conclusions from a randomized, double-blind, controlled prospective study of olanzapine, risperidone, and haloperidol. J Clin Psychopharmacol. 2008 Feb;28(1):27-31.

25. Shrivastava A, Johnston M, Bureau Y, Shah N. Baseline serum prolactin in drug-naive, first-episode schizophrenia and outcome at five years: is it a predictive factor? Innov Clin Neurosci. 2012 Apr;9(4):17-21.

26. Shrivastava A, Shah N, Johnston M, Stitt L, Thakar M, Chinnasamy G. Effects of duration of untreated psychosis on long-term outcome of people hospitalized with first episode schizophre. Indian J Psychiatry. 2010 Apr;52(2):164-7.

27. Shrivastava A, Johnston M, Thakar M, Stitt L, Shah N. Social outcome in clinically recovered first-episode schizophrenia in a naturalistic, ten-year, follow-up study in India. Clin Schizophr Relat Psychoses. 2011 Jul;5(2):95-101.

28. Chugh PK, Rehan HS, Unni KES, Sah RK. Predictive value of symptoms for quality of life in first-episode schizophrenia. Nord $\mathbf{J}$ Psychiatry. 2013 Jun;67(3):153-8.

29. Johnson S, Sathyaseelan M, Charles H, Jacob KS. Predictors of disability: a 5-year cohort study of first-episode schizophrenia. Asian J Psychiatry. 2014 Jun;9:45-50.

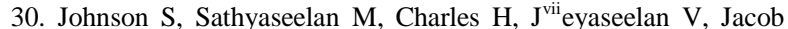
KS. Predictors of insight in first-episode schizophrenia: a 5-year cohort study from India. Int J Soc Psychiatry. 2014 Sep;60(6):56674.

31. Raghavan V, Ramamurthy M, Rangaswamy T. Social functioning in individuals with first episode psychosis: One-year follow-up study. Asian J Psychiatry. 2017 Dec;30:124-6.

32. Rangaswamy T, Mangala R, Mohan G, Joseph J, John S. Intervention for first episode psychosis in India - The SCARF experience. Asian J Psychiatry. 2012 Mar;5(1):58-62.

33. Iyer SN, Mangala R, Anitha J, Thara R, Malla AK. An examination of patient-identified goals for treatment in a first-episode programme in Chennai, India. Early Interv Psychiatry [Internet]. 2011 [cited 2016 Jun 26];5(4):360-365. Available from: http://onlinelibrary.wiley.com/doi/10.1111/j.1751-

7893.2011.00289.x/full

34. Tharoor H, Ganesh A. Symptoms at Onset in First Episode Schizophrenia: Caregivers Perspectives. Indian J Psychol Med. 2015 Dec;37(4):399-402.
35. Sadath A, Muralidhar D, Varambally S, Gangadhar BN, Jose JP. Do stress and support matter for caring? The role of perceived stress and social support on expressed emotion of carers of persons with first episode psychosis. Asian J Psychiatry [Internet]. 2017 [cited 2017 Feb 10];25:163-168. Available from: http://www.sciencedirect.com/science/article/pii/S187620181530082

36. Shrivastava A, Johnston M, Terpstra K, Stitt L, Shah N. Atypical antipsychotics usage in long-term follow-up of first episode schizophrenia. Indian J Psychiatry. 2012 Jul;54(3):248-52.

37. Sahni S, Chavan BS, Sidana A, Kalra P, Kaur G. Comparative study of clozapine versus risperidone in treatment-naive, firstepisode schizophrenia: A pilot study. Indian J Med Res. 2016 Nov;144(5):697-703.

38. Hegde S, Rao SL, Raguram A, Gangadhar BN. Addition of home-based cognitive retraining to treatment as usual in first episode schizophrenia patients: a randomized controlled study. Indian J Psychiatry. 2012 Jan;54(1):15-22.

39. Shrivastava AK, Johnston ME, Stitt L, Thakar M, Sakel G, Iyer $\mathrm{S}$, et al. Reducing treatment delay for early intervention: evaluation of a community based crisis helpline. Ann Gen Psychiatry. 2012 Jul $24 ; 11(1): 20$.

40. Morgan C, Hibben M, Esan O, John S, Patel V, Weiss HA, et al. Searching for psychosis: INTREPID (1): systems for detecting untreated and first-episode cases of psychosis in diverse settings. Soc Psychiatry Psychiatr Epidemiol. 2015 Jun;50(6):879-93.

41. Shiers D, Lester H. Early intervention for first episode psychosis: Needs greater involvement of primary care professionals for its success. BMJ. 2004;328(7454):1451.

42. Erritty P, Wydell TN. Are Lay People Good at Recognising the Symptoms of Schizophrenia? PLoS ONE [Internet]. 2013 Jan 2 [cited 2018 May 6];8(1). Available from: https://www.ncbi.nlm.nih.gov/pmc/articles/PMC3534720/

43. Johannessen JO, Friis S, Joa I, Haahr U, Larsen TK, Melle I, et al. First-episode psychosis patients recruited into treatment via early detection teams versus ordinary pathways: course, outcome and health service use during first 2 years. Early Interv Psychiatry. 2007;1(1):40-48.

44. Jorm AF, Wright A, Morgan AJ. Beliefs about appropriate first aid for young people with mental disorders: findings from an Australian national survey of youth and parents. Early Interv Psychiatry. 2007;1(1):61-70.

45. Friis S, Melle I, Larsen TK, Haahr U, Johannessen JO, Simonsen $\mathrm{E}$, et al. Does duration of untreated psychosis bias study samples of first-episode psychosis? Acta Psychiatr Scand. 2004;110(4):286291.

46. Berger G, Fraser R, Carbone S, McGorry P. Emerging psychosis in young people-Part I. Key issues for detection and assessment: Aust Fam Physician. 2006 May;35(5):315-21

47. Hopkins G. In sight, in mind. Community Care. 2002;1436:40 41.

48. Radhakrishnan R, Andrade C. Suicide: An Indian perspective. Indian J Psychiatry [Internet]. 2012 [cited 2018 May 6];54(4):30419.

49. Welch M, Garland G. The safe way to early intervention: an account of the SAFE (Southern Area First Episode) Project. Australas Psyc viii hiatry. 2000;8(3):243-248. 
50. Csillag C, Nordentoft M, Mizuno M, Jones PB, Killackey E, Taylor M, et al. Early intervention services in psychosis: from evidence to wide implementation. Early Interv Psychiatry. 2016;10(6):540-546.

51. McGorry P. Early psychosis prevention and intervention centre. Australas Psychiatry. 1993;1(1):32-34.
52. McGorry PD, Tanti C, Stokes R, Hickie IB, Carnell K, Littlefield LK, et al. headspace: Australia's National Youth Mental Health Foundation-where young minds come first. Med J Aust. 2007;187(7):S68. 
(C) 2018 IJMHNS

(C2018 IJMHNS

(C)2018 IJMHNS

(C)2018 IJMHNS

C 2018 IJMHNS

(C) 2018 IJMHNS

() 2018 IJMHNS

(C) 2018 IJMHNS 